\title{
The Use of Hyaluronate in Flexor Tendon Surgery in the Hand to Prevent Post-Operative Adhesions: A Prospective Comparative Study
}

\author{
MENA NAGUIB, M.Sc.2; AHMED S. HWEIDI, M.D.1; DALIA M.E. EL MIKKAWY, M.D. ${ }^{3}$ and \\ AYMAN ABD RABU, M.D. 4
}

The Department of Plastic and Reconstructive Surgery, Faculty of Medicine, Ain Shams University 1 , The Department of Surgery, Police Academy Hospital, Ministery of Interior ${ }^{2}$, The Departments of Physiotherapy \& Rehabilitation ${ }^{3}$ and General Surgery ${ }^{4}$, Faculty of Medicine, Ain Shams University, Cairo

\begin{abstract}
Material and Methods: 40 digits were split into 2 groups to study the effect of hyaluronic acid injection in reducing the post-operative adhesions after flexor tendon repair surgery.

Results: The study group showed better range of movements and less stiffness than the control group.
\end{abstract}

Key Words: Hand trauma - Flexor tendon repair - Flexor muscle function - Hyaluronic acid - Cruciate repair.

\section{INTRODUCTION}

In the past, the results of primary tendon repair in zone II were not very promising. This pushed surgeons to consider delayed tendon grafting of flexor digitorum profundus as the standard treatment. Nowadays, with the improvement of surgical techniques, suture materials, together with the concept of early post-operative mobilization, the superiority of primary repair for flexor tendon injuries was established [1].

Several attempts have been made in order to minimize adhesions and therefore improve the results in terms of range of movement after flexor tendon surgery using various pharmacologic agents such as 5-fluorouracil, indomethacin and ibuprofen [2-4].

Ozgenel and ETÖZ adopted the technique of multiple injections; the first dose was given at the time of tendon repair surgery and two additional doses were given after 1 week and 2 weeks postoperative [5].

Generally, HA has a positive effect on tendon healing which is based on its anti-inflammatory action, cell proliferation enhancement, and deposition of collagen, besides the lubricating action on the tendon sliding.
There are complex biological activities of HA, such as: (A) Inhibition of Matrix Metalloproteinases (MMPs) and the phagocytic activity of macrophages and leukocytes; (B) Promoting the release of prostaglandins and enhancing the normalization of endogenous hyaluronan synthesis; (C) Being a free radicals scavenger and stimulating proteoglycans synthesis [6].

Actually, HA is actively secreted by the tendon sheath being an important component of the synovial fluid, which allows gliding of tendon smoothly, and provides nutrition to tendon itself. Moreover, it is also an important component of tendon structure, and is present massively in extracellular space [7].

The aim of our study is assessing the effect of hyaluronate injection intra-and post-operative within the fibro-osseus sheath in flexor tendon repairs to minimize post-operative adhesions and improve tendon gliding.

\section{PATIENTS AND METHODS}

This is a prospective randomized controlled clinical trial, conducted at Ain Shams University Hospitals on patients presenting from January to September 2017 at Ain Shams University Hospitals.

This study was conducted on 40 digits for patients presenting to Ain Shams Hospitals, presenting with isolated zone II flexor tendon injuries Scheduled for primary repair.

Patients were randomly split into 2 groups, Group (A) where patients were subjected to hyaluronic acid injection within the flexor tendon 
sheath intra operative and in follow-up (20 patients) those patients were selected of those who were admitted to the department on Saturdays, Mondays, and Wednesdays of the weeks of the trial, while Group (B) where patients were subjected to placebo (Normal Saline) injection within the flexor tendon sheath intra-operative and in follow-ups. (20 patients) those patients were selected of those who were admitted to the department on Sundays, Tuesdays, and Thursdays of the weeks of the trial.

The study was double-blinded for both the patient and the physiotherapist.

All cases were operated by the same surgeon, same technique; cruciate repair with epitendeous sutures and introduced to the same rehabilitation program.

All patients signed an informed consent form beforehand. The personal data and medical information of all patients were reported confidentially.

\section{Inclusion criteria:}

Ages of the participants were between 12-65 years with no gender restriction with recent Zone 2 flexor tendon injuries only.

\section{Exclusion criteria:}

Devascularized or devitalized soft tissue and associated nerve injury affecting the range of movement with associated bony fractures and significant proximal tendinous end retraction beyond zone III; also injuries occurring within 24 hours prior to repair with significant contamination as well as severe hand injuries with skin loss requiring coverage.

All patients were subjected to clinical examination to determine the site of wound, whether the wound is clean or contaminated, sharp or lacerated wound. Also careful examination of the neurovascular status of the hand: Evaluation of the sensory and motor functions of median, ulnar and radial nerves to exclude associated nerve injury, and checking vascularity by capillary refill test as well as peripheral pulsations. Tendon function was evaluated with voluntary active movements of the finger. Also; bone examination to exclude crepitus, edema and deformities.

Routine pre-operative investigations were requested for all patients, including complete blood picture, coagulation profile, liver and kidney function tests, fasting blood sugar, and ECG for those above forty years old. X-ray hand antero-posterior and oblique views were done to exclude associated bone fractures.

\section{Operative technique:}

Surgical repair was done either under general or regional anesthesia (supra clavicular block). Pneumatic tourniquet was used in all cases to provide an avascular field during surgery.

The wound is thoroughly cleaned and irrigated with saline solution. Pre-operative antibiotic prophylaxes were administered to all cases.

All patient were operated upon in supine position using hand surgery extension table with shoulder abduction. Prophylactic antibiotics were administered on induction in all cases based on our hospital protocols. Then the hand and forearm were draped and prepared for surgery.

The wound is examined, and then incisions are planned that would allow access to proximal and distal tendon ends.

The skin and subcutaneous fat are raised off of the tendon sheath as a single thick layer.

The distal tendon end may often be delivered by passive flexion of the DIP and PIP joints. The proximal tendon end may be visible within the fibro-osseous sheath. Retrieval of the proximal end may be done using many techniques; we usually give just one attempt to grasp the edge of the tendon using a mosquito forceps, if grasped we pull it distally and secure it in place with a fine needle going transversely through the tendon and adjacent soft tissue Fig. (1). If not accessible, particularly if injury happened during hand flexion, retrieval of the proximal end was aided by milking of the forearm and hand across the course of the tendon. If the tendon end is still not visible, the wound is extended, and retrieval is achieved through proximal palm incision, after which the tendon is delivered to the trauma site again by the aid of infantile nasogastric tube or a small Nelaton catheter.

Neurovascular structures are identified and checked for injuries and managed if found.

Surgical repair was performed using 4-stranded cruciate repair using Prolene 4/0 because it is a stronger tensile strength that resists rupture, and repair site gapping, and allows early active mobilization protocol Fig. (2).

To smooth and strengthen the site of tendon repair, epitendinous sutures were taken by Prolene 6/0 sutures. Therefore epitendinous Sutures con- 
sidered an important adjunct to core tendon suture [8] Fig. (3).

To adjust the tension after the repair, the hand is left to show the normal cascade, we test the gliding after the repair by flexing the repaired tendon several times.

Hyaluronic acid injection at the repair site intra-operative:

After the completion of the repair, a 18 Gauge cannula is introduced into the digital sheath in both proximal and distal ends of the repaired tendon through which $2 \mathrm{mls}$ of Hyaluronic Acid (Hyalgan) are injected after the release of tourniquet and hemostasis and before skin closure Fig. (4).

Hyalgan is a viscous solution with a high molecular weight $(500,000-730,000)$ daltons. Fraction of purified natural sodium hyaluronate in buffered physiological sodium chloride, having a $\mathrm{pH}$ of 6.87.5 .

Post-operative follow-up and injection of hyaluronic acid:

We started physiotherapy in all patients on the $3^{\text {rd }}$ day after surgery-in case of injury to neurovascular bundle, rehabilitation was started on the $10^{\text {th }}$ post-operative day. Post-operative antibiotics, analgesics and anti-edematous measures are prescribed for all cases.

Weekly visits are scheduled for the patients, $2 \mathrm{mls}$ of Hyaluronic acid are injected after one week post-operative and another $2 \mathrm{mls}$ are injected after two weeks post-operative.

The injection site is prepared with Alcohol swab, then the tip of the 27 Gauge Needle is inserted proximally and distally at the site of the injury in the finger and angled approximately $45^{\circ}$ both proximally and distally.

The tip is advanced blindly through skin, fibroosseus sheath till it hits the tendon, then the tip is slowly withdrawn $1-2 \mathrm{~mm}$ indicating that the needle is within the flexor tendon sheath. This injection should not require any force in a similar technique like injecting steroids in the flexor sheath as in cases of trigger finger treatment [9].

Then $2 \mathrm{mls}$ of Hyaluronic Acid are injected into the flexor tendon sheath, $1 \mathrm{ml}$ proximal and $1 \mathrm{ml}$ distal to the repair site.

In the control group, the same procedure was performed using physiological saline.
Assessment: After 12 weeks, we used a goniometer to assess the range of motion of MCP, PIP and DIP joints of each finger Fig. (5).

The passive and active range of motion values for the three joints in each finger were summed up as the total range of passive motion (TPM) and the total range of active motion (TAM).

The long-term follow-up for the final active motion of each operated finger was done using the modified strickland grading system. The active motion value was calculated by subtracting the extension deficit of the involved joints from the maximal possible flexion. Results were classified as; excellent if $>131^{\circ}$, good if $88-131^{\circ}$, fair if 44$87^{\circ}$ and poor if $<44^{\circ}$.

\section{Rehabilitation and post-operative care;}

Program of early active mobilization (active place and hold), this program was divided into four phases as follows [10]:

In the post-operative phase I which takes from 1-4 weeks starting from 1 day post-operatively and continuing to 4 weeks where active place-hold (we passively place the digits into flexion and then instruct the patient to actively maintain the position with gentle muscle contraction). Where composite and straight fist exercises are performed Fig. (7).

Tenodesis exercises involved active digital extension with the wrist flexed. FDS and FDP blocking exercises are performed for uninvolved digits. Passive flexion and active extension to Proximal Inter Phalangeal (PIP) and Distal Inter Phalangeal (DIP) joints till the limit of the splint.

Phase II from 4-6 weeks where we continue with dorsal blocking splint and continue passive flexion active extension to PIP and DIP joints in addition to beginning place and hold active hook fist exercises as well as active tenodesis exercises, with composite, straight, hook, and tabletop fists.

Then phase III from 6-8 weeks where the dorsal blocking splint is removed and active tenodesis exercises are continued in addition to active tendon glide exercises with gentle blocking exercises to FDS and FDP to start at 6 weeks for the involved digit Fig. (8). Also isometric pinch and grip exercises are performed.

Finally phase IV in 8-12 weeks where active and resistive exercises are continued (hand grip and pinch against resistance) [11]. 


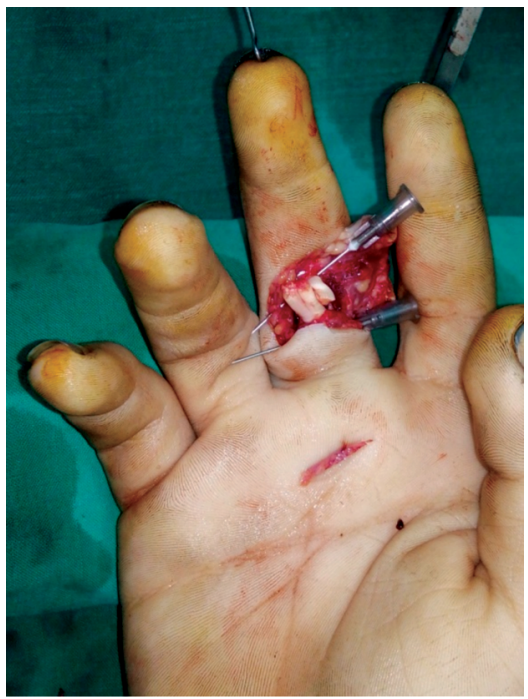

Fig. (1): Maintaining the tendon position after retrieval of proximal and distal ends.
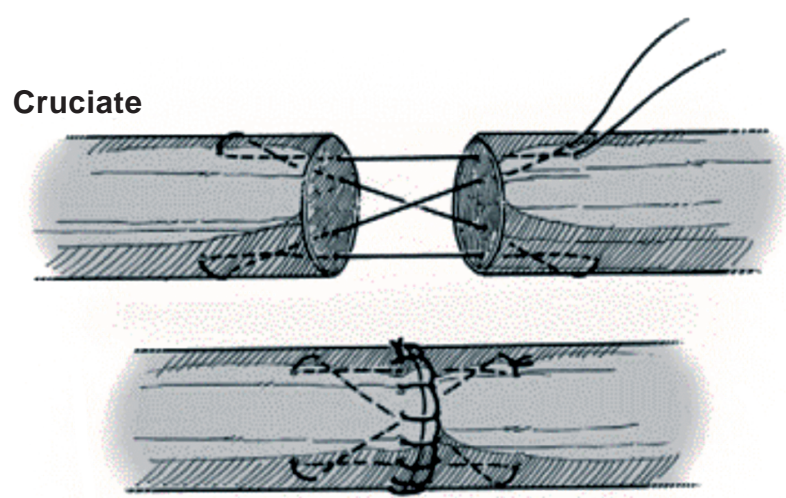

Fig. (2): The cruciate technique of tendon repair.

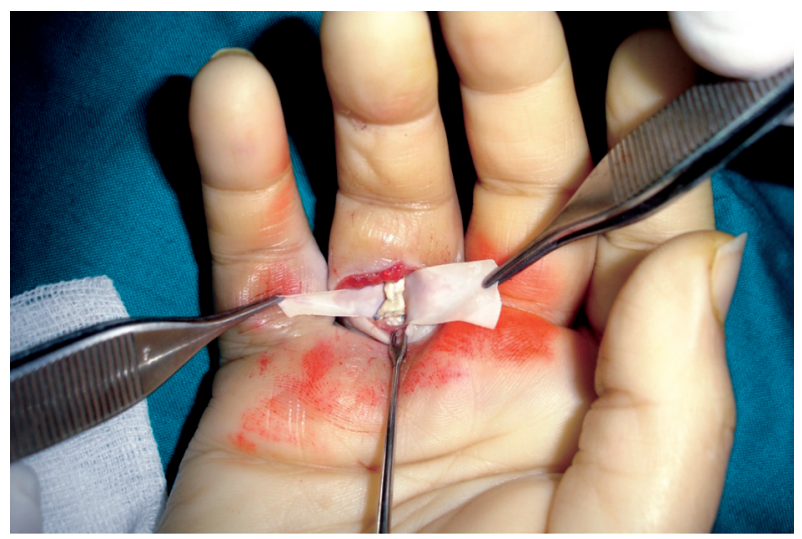

Fig. (3): Epitendineous sutures using Prolene 6-0.

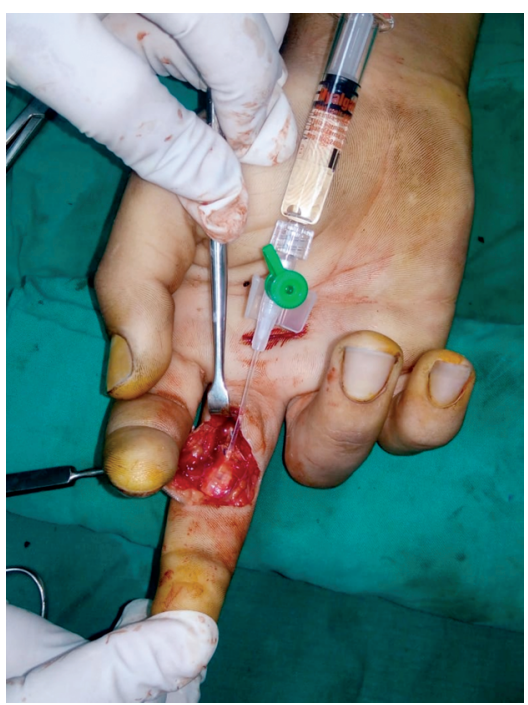

Fig. (4): Injection of hyaluronic acid at the repair site.
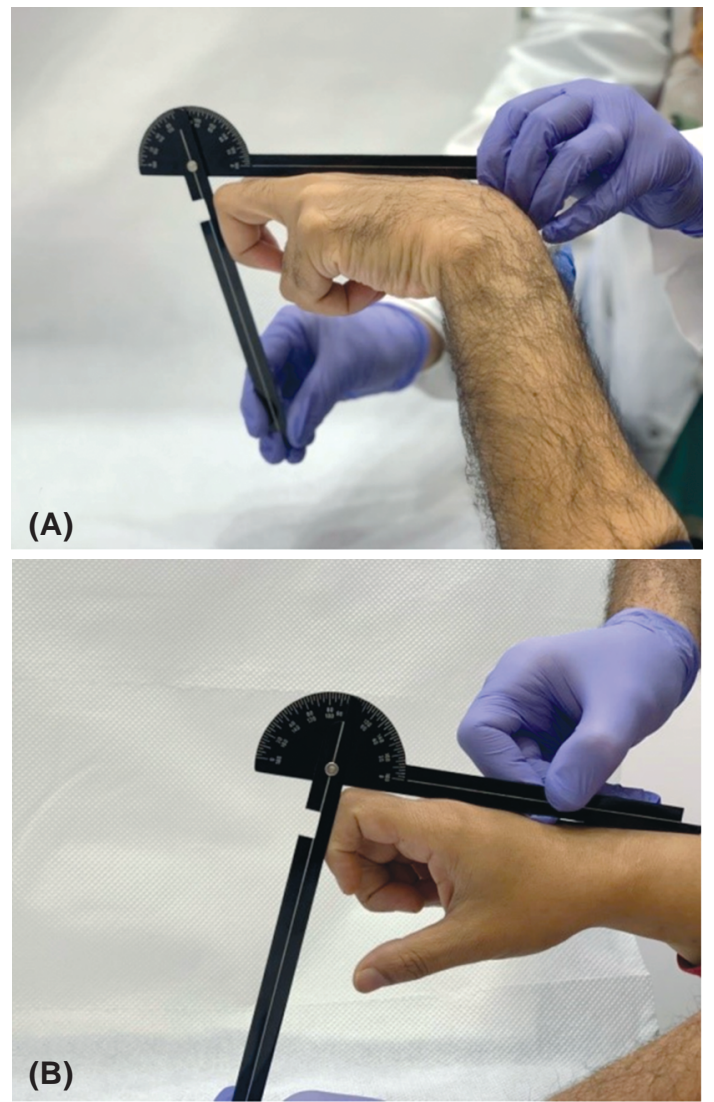

Fig. (5): Measurement of the range of motion using goniomete.

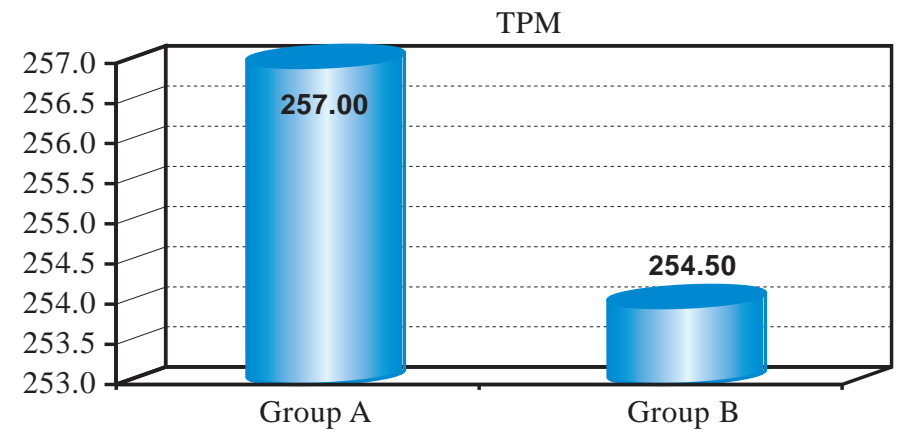

Fig. (6): TPM in both Groups A \& B. 

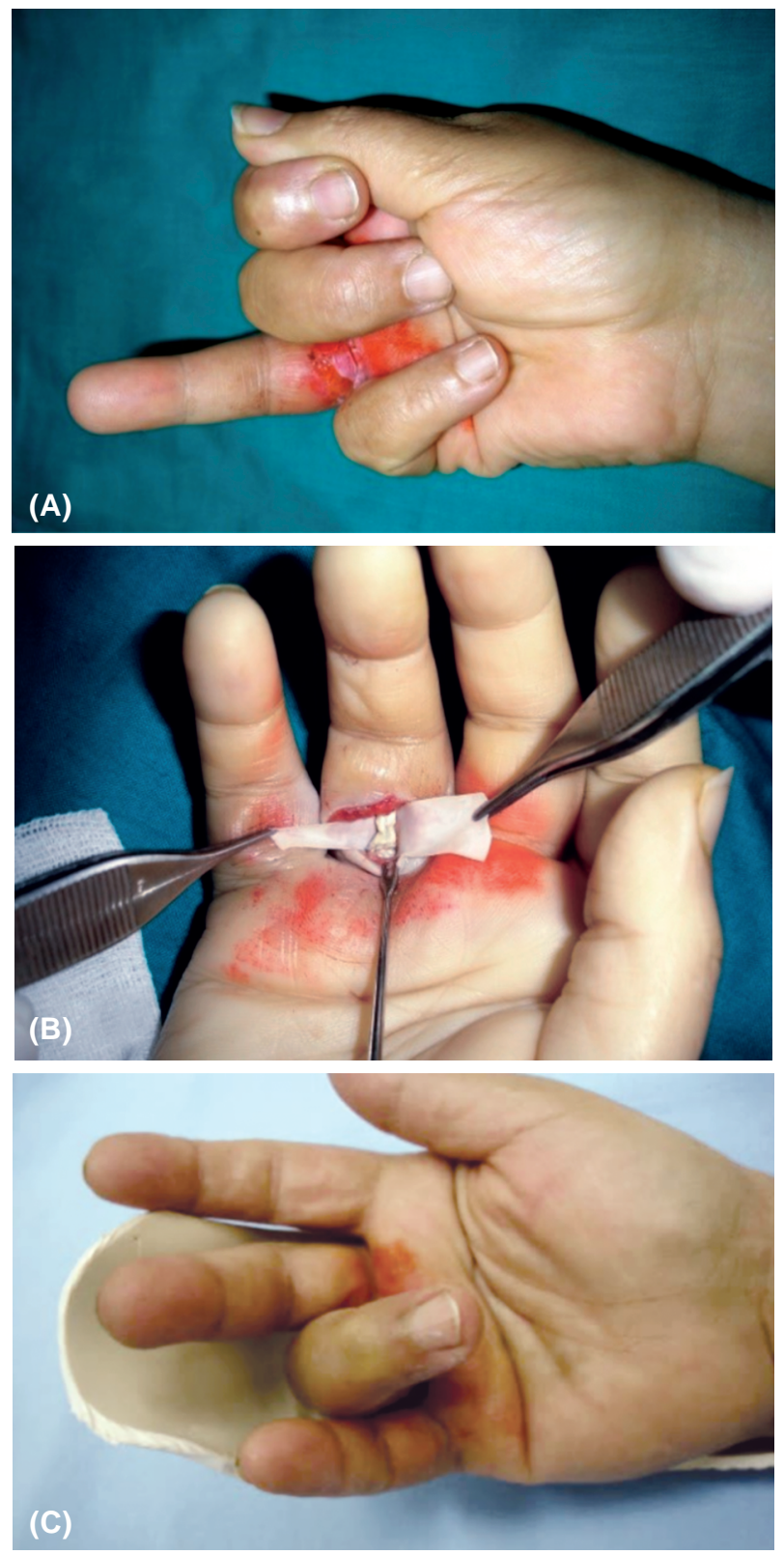

Fig. (7): Stages of the study. (A) Represents the injury during pre-operative examination, (B) Shows the surgical technique of repair, intraoperative, while (C) Shows the motion of the treated finger after 4 weeks of operation.

\section{RESULTS}

The socio-demographic data of Group A \& B show that there was no statistically significant difference found between Group A and Group B regarding sex, age causative instrument and hand while there was statistically significant difference found between them regarding finger. As shown in (Table 2).

There is an increase in the Total Passive Movement (TPM) in the study group which was treated by hyaluronic acid injection. Fig. (6) and (Table 3).
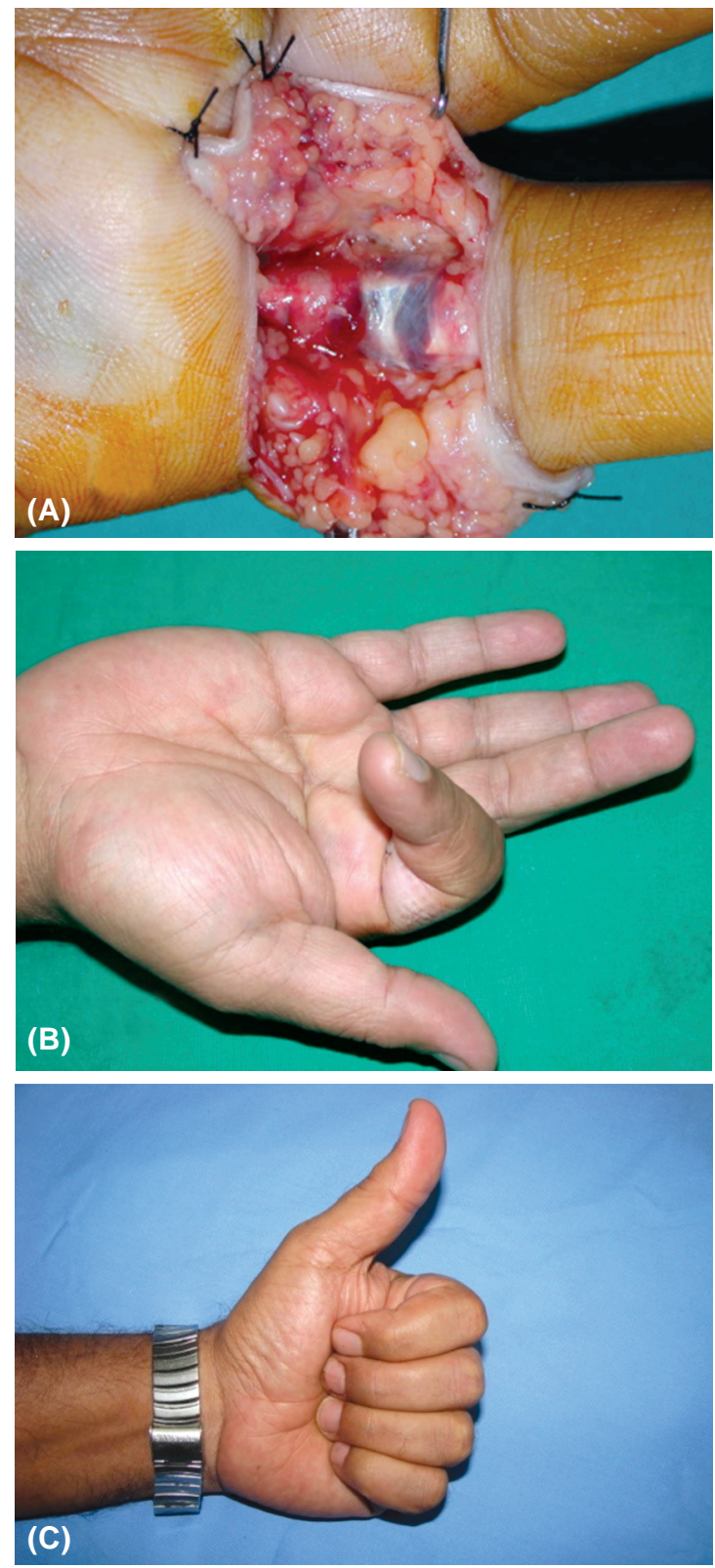

Fig. (8): Another case treated with HA injection. (A) Shows the tendon injury with obvious hematoma at the site of injury, (B) Shows results after 5 weeks postoperative, (C) Shows the result after 3 months.

As shown in (Table 4) and with clinical observation, the range of motion is better in the study Group (A) after treatment with HA injection. Figs. $(7,8)$.

The statistical analysis of the range of motion over the 3 joints MCP, PIP and DIP reveals significant improvement in the active PIP and DIP in the study Group (A) which was treated with the injection of HA. While there was a decline in the active MCP in the same group compared to the control group Figs. $(9,10)$ (Table 5). 
The statistical analysis show there is an increase of the total active motion of the study Group (A) compared to the control Group (B) Fig. (11), (Table 6).

The analysis of the rate and type of complications reveals that the rate of injection is higher $(10 \%)$ in the study Group (A), for (5\%) in the control Group (B). However, no cases were complicated by stiffness in the study Group (A), compared to $20 \%$ in control Group (B) Fig. (12), (Table 7).

The data representation show an increase in the adjust strickland score in Group A, than in Group $\mathrm{B}$; which significance that there is an improvement with the treatment of flexor tendons with hypo acid, represented by better adjusted strickland scores and grades Figs. $(13,14)$, (Table 8).

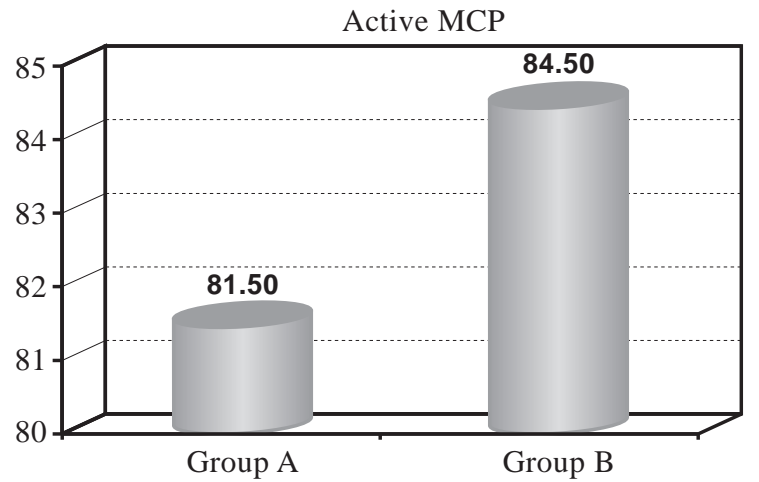

Fig. (9): Active range of motion at MCP of both Groups A \& B.

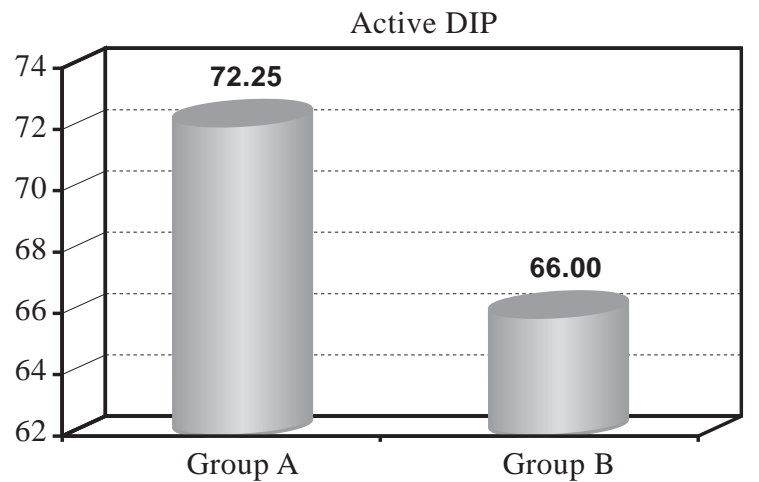

Fig. (10): Active range of motion at DIP in both groups.

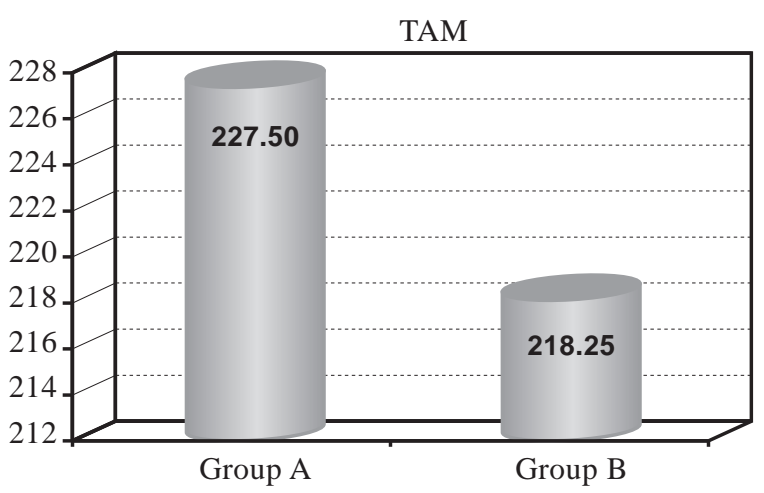

Fig. (11): TAM comparison between Group A \& B.

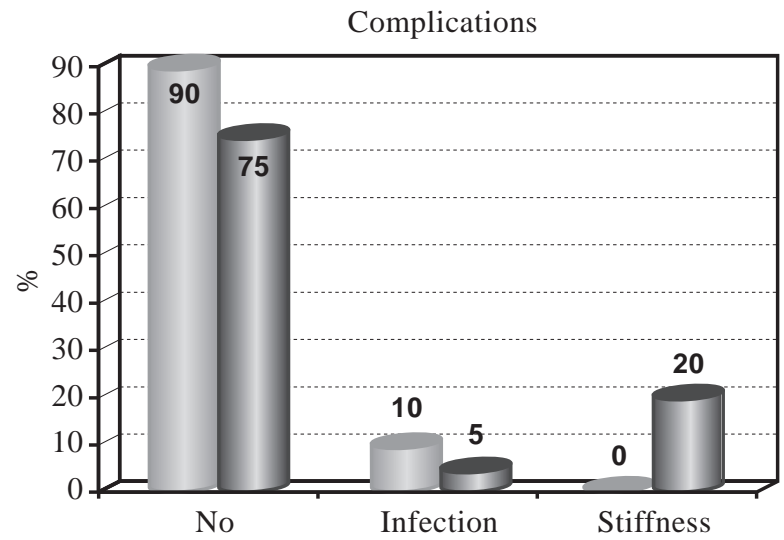

complications

Group A $\square$ Group B

Fig. (12): Complications in both Groups A \& B.

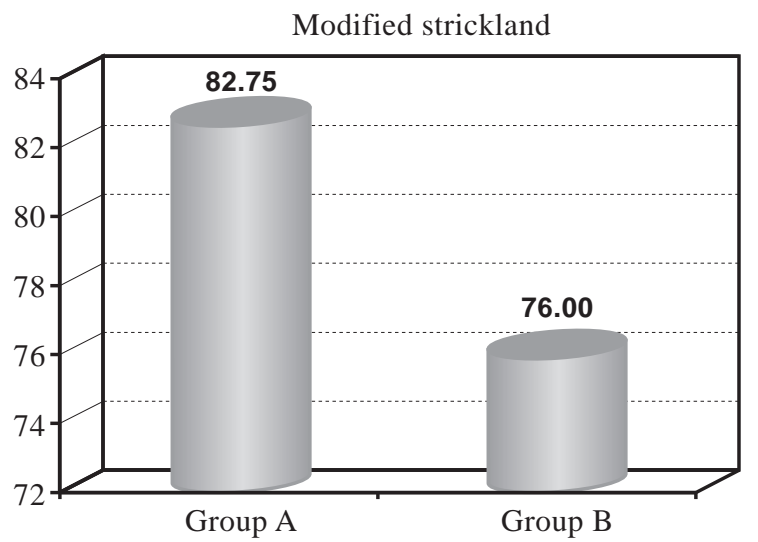

Fig. (13): Adjusted strickland score for both Groups A \& B

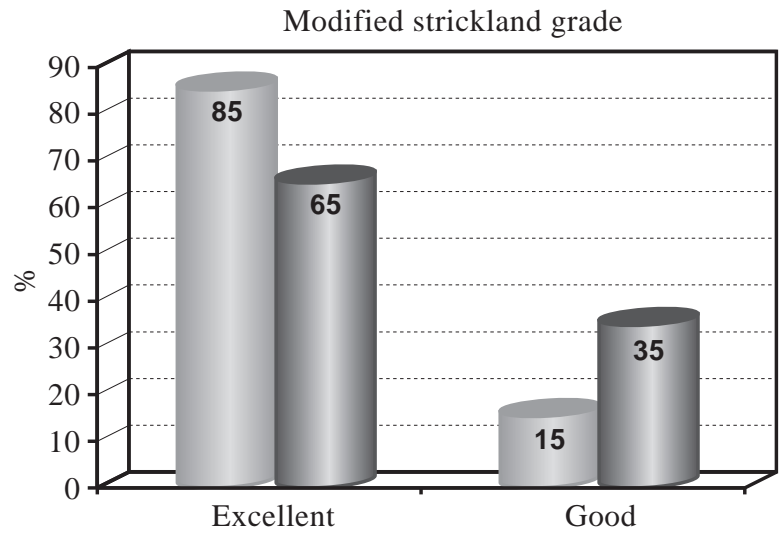

Group A Group B

Fig. (14): A.S grade for both or A \& B.

Table (1): Strickland's evaluation systems.

\begin{tabular}{lcc}
\hline Score & $\begin{array}{c}\text { Original Strickland } \\
\%\end{array}$ & $\begin{array}{c}\text { Adjusted Strickland } \\
\%\end{array}$ \\
\hline Excellent & $85-100$ & $75-100$ \\
Good & $70-84$ & $50-74$ \\
Fair & $50-69$ & $24-49$ \\
Poor & $<50$ & $0-24$ \\
\hline
\end{tabular}


Table (2): Comparison between Group A and Group B regarding socio-demographic data.

\begin{tabular}{|c|c|c|c|c|c|}
\hline $\begin{array}{l}\text { Socio-demographic } \\
\text { data }\end{array}$ & $\begin{array}{l}\text { Group A } \\
\text { No. }=20\end{array}$ & $\begin{array}{l}\text { Group B } \\
\text { No. }=20\end{array}$ & $\begin{array}{c}\text { Test } \\
\text { value }\end{array}$ & $\begin{array}{c}p- \\
\text { value }\end{array}$ & Sig. \\
\hline \multicolumn{6}{|l|}{ Sex: } \\
\hline Females & $3(15.0 \%)$ & $7 \quad(35.0 \%)$ & $2.133^{*}$ & 0.144 & NS \\
\hline Males & $17(85.0 \%)$ & $13(65.0 \%)$ & & & \\
\hline \multicolumn{6}{|l|}{ Age: } \\
\hline Mean \pm SD & $28.95 \pm 10.85$ & $27.95 \pm 10.93$ & $-0.290 \bullet$ & 0.773 & NS \\
\hline Range & $17-44$ & $15-41$ & & & \\
\hline \multicolumn{6}{|l|}{ Causative } \\
\hline $\begin{array}{l}\text { instrument: } \\
\text { Electric saw }\end{array}$ & $2(10.0 \%)$ & $0 \quad(0.0 \%)$ & $6.053 *$ & 0.109 & NS \\
\hline Glass & $9(45.0 \%)$ & $10(50.0 \%)$ & & & \\
\hline Knife & $6(30.0 \%)$ & $10(50.0 \%)$ & & & \\
\hline Metal coil & $3(15.0 \%)$ & $0(0.0 \%)$ & & & \\
\hline \multicolumn{6}{|l|}{ Hand: } \\
\hline Left & $8 \quad(40.0 \%)$ & $13(65.0 \%)$ & $2.506^{*}$ & 0.113 & NS \\
\hline Right & $12(60.0 \%)$ & $7 \quad(35.0 \%)$ & & & \\
\hline \multicolumn{6}{|l|}{ Finger: } \\
\hline Index & $0 \quad(0.0 \%)$ & $3 \quad(15.0 \%)$ & $10.000 *$ & 0.019 & $\mathrm{~S}$ \\
\hline Little & $6 \quad(30.0 \%)$ & $0 \quad(0.0 \%)$ & & & \\
\hline Middle & $3(15.0 \%)$ & $6 \quad(30.0 \%)$ & & & \\
\hline Ring & $11(55.0 \%)$ & $11(55.0 \%)$ & & & \\
\hline $\begin{array}{l}-\quad \text { : Independent } t \text {-t } \\
* \quad \text { : Chi-square test } \\
\text { HS : Highly Signific }\end{array}$ & est. & $\begin{array}{l}\text { S : Signific } \\
\text { NS : Non Sig }\end{array}$ & $\begin{array}{l}\text { ant. } \\
\text { nificant. }\end{array}$ & & \\
\hline
\end{tabular}

Table (3): Comparison between TPM of the injured hand in both Groups A \& B.

\begin{tabular}{llllll}
\hline TPM normal & $\begin{array}{c}\text { Group A } \\
\text { No.=20 }\end{array}$ & $\begin{array}{c}\text { Group B } \\
\text { No.=20 }\end{array}$ & $\begin{array}{c}\text { Test } \\
\text { value }\end{array}$ & $\begin{array}{c}p \text { - } \\
\text { value }\end{array}$ & Sig. \\
\hline Mean \pm SD & $\begin{array}{l}257.00 \pm 15.59 \\
230-270\end{array}$ & $\begin{array}{l}254.50 \pm 23.28 \\
210-270\end{array}$ & -0.399 & 0.692 & NS \\
Range & S : Significant. & & \\
\hline$\quad$ : Independent $t$-test. & NS : Non Significant. & & \\
HS : Highly Significant. & S & & &
\end{tabular}

Table (4): Comparison between range of movement in both Groups A \& B.

\begin{tabular}{|c|c|c|c|c|c|}
\hline Injured hand & $\begin{array}{c}\text { Group A } \\
\text { No. }=20\end{array}$ & $\begin{array}{c}\text { Group B } \\
\text { No. }=20\end{array}$ & $\begin{array}{c}\text { Test } \\
\text { value• }\end{array}$ & $\begin{array}{c}p- \\
\text { value }\end{array}$ & Sig. \\
\hline $\begin{array}{l}\text { Active } M C P \text { : } \\
\quad \text { Mean } \pm \mathrm{SD} \\
\text { Range }\end{array}$ & $\begin{array}{l}81.50 \pm 3.66 \\
80-90\end{array}$ & $\begin{array}{l}84.50 \pm 5.10 \\
80-90\end{array}$ & 2.135 & 0.039 & $\mathrm{~S}$ \\
\hline $\begin{array}{l}\text { Active PIP: } \\
\quad \text { Mean } \pm \mathrm{SD} \\
\quad \text { Range }\end{array}$ & $\begin{array}{l}73.75 \pm 15.03 \\
40-85\end{array}$ & $\begin{array}{l}67.75 \pm 15.34 \\
40-80\end{array}$ & -1.249 & 0.219 & NS \\
\hline $\begin{array}{l}\text { Active DIP: } \\
\quad \text { Mean } \pm \mathrm{SD} \\
\quad \text { Range }\end{array}$ & $\begin{array}{l}72.25 \pm 6.78 \\
60-80\end{array}$ & $\begin{array}{l}66.00 \pm 9.54 \\
50-75\end{array}$ & -2.388 & 0.022 & $\mathrm{~S}$ \\
\hline
\end{tabular}

Table (5): Comparison between TAM of both Groups A \& B.

\begin{tabular}{lccccc}
$\begin{array}{l}\text { TAM } \\
\text { injured hand }\end{array}$ & $\begin{array}{c}\text { Group A } \\
\text { No.=20 }\end{array}$ & $\begin{array}{c}\text { Group B } \\
\text { No. }=20\end{array}$ & $\begin{array}{c}\text { Test } \\
\text { value }\end{array}$ & $\begin{array}{c}p \text { - } \\
\text { value }\end{array}$ & Sig. \\
\hline $\begin{array}{l}\text { Mean } \pm \text { SD } \\
\text { Range }\end{array}$ & $\begin{array}{l}227.50 \pm 21.12 \\
180-245\end{array}$ & $\begin{array}{l}218.25 \pm 27.21 \\
170-245\end{array}$ & -1.201 & 0.237 & NS \\
\hline : Independent $t$-test. & S : Significant. & & \\
HS : Highly Significant. & NS : Non Significant. &
\end{tabular}

Table (6): Comparison between the rates of complication in both Groups A \& B.

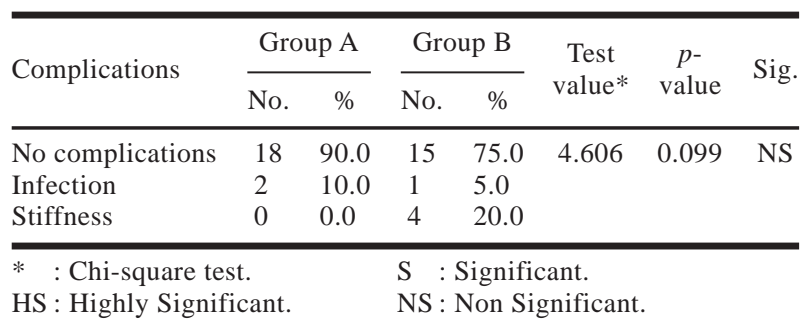

Table (7): Comparison between the adjusted Strickland score for Groups A \& B.

\begin{tabular}{|c|c|c|c|c|c|}
\hline $\begin{array}{l}\text { Modified } \\
\text { Strickland }\end{array}$ & $\begin{array}{c}\text { Group A } \\
\text { No. }=20\end{array}$ & $\begin{array}{c}\text { Group B } \\
\text { No. }=20\end{array}$ & $\begin{array}{c}\text { Test } \\
\text { value• }\end{array}$ & $\begin{array}{c}p- \\
\text { value }\end{array}$ & Sig. \\
\hline $\begin{array}{l}\text { Mean } \pm S D \\
\text { Range }\end{array}$ & $\begin{array}{l}82.75 \pm 11.85 \\
57-94\end{array}$ & $\begin{array}{l}76.00 \pm 14.04 \\
51-88\end{array}$ & -1.643 & 0.109 & NS \\
\hline
\end{tabular}

Table (8): Comparison between A.S grade for both Groups A \& B.

\begin{tabular}{|c|c|c|c|c|c|c|c|}
\hline \multirow{2}{*}{$\begin{array}{l}\text { Modified } \\
\text { Strickland } \\
\text { Grade }\end{array}$} & \multicolumn{2}{|c|}{ Group A } & \multicolumn{2}{|c|}{ Group B } & \multirow{2}{*}{$\begin{array}{c}\text { Test } \\
\text { value* }\end{array}$} & \multirow{2}{*}{$\begin{array}{c}p- \\
\text { value }\end{array}$} & \multirow{2}{*}{ Sig. } \\
\hline & No. & $\%$ & No. & $\%$ & & & \\
\hline Excellent & 17 & 85.0 & 13 & 65.0 & 2.133 & 0.144 & NS \\
\hline Good & 3 & 15.0 & 7 & 35.0 & & & \\
\hline
\end{tabular}

\section{DISCUSSION}

The aim of this study is to compare the effects of repeated injections of hyalorinate versus placebo injection (normal saline) on the functional outcome following the primary repair of zone II flexor tendon injury.

The first study aimed to assess the effect of HA injection on prevention of adhesions in flexor tendon surgery was performed by Lars Hagberg in which he demonstrated no significant benefit of hyalorinate injection in single-dose intraoperatively during the flexor tendon repair, as it is rapidly eliminated from the tendon sheath [12].

Güzin Ozgenel and Abdullah ETÖZ adopted the technique of multiple injections; the first dose was given at the time of tendon repair during surgery and two additional doses were given at one-week intervals. In our study we decided to inject HA repetitively to provide maintenance of sufficient doses to reduce post-operative adhesions and increase the range of motion [5].

Ozgenel and ETÖZ also introduced a $23 \mathrm{G}$ catheter with its tip placed near the FDP repair site and 
threaded subcutaneously, to exit the skin at A1 pulley level, the catheter was then fixed to the skin at the exit site [5].

We believe that this technique could be unsafe and impractical, for fear of compromising the repair due to the high possibility of infection; even with the use of antibiotics. In our study we injected the intra-operative dose using a syringe not a preinserted cannula $1 \mathrm{ml}$ proximal and $1 \mathrm{ml}$ distal to the repair site, then we closed the skin, the later injections were performed by the same technique used to inject corticosteroids in trigger finger; which we thought is safer for the patients by protecting the repair site.

In their study; Güzin Ozgenel and Abdullah ETÖZ adopted the modified Kessler technique using Prolene 4/0 sutures followed by epitendinous running suture using Prolene 6/0. We preferred the cruciate repair since we started using it in our department in 2013 as it provided stronger tenorraphy with less gaping and more ability to withstand early active mobilization with massive reduction of the rupture rate [5].

In Conclusion: The study we have performed revealed that the repeated injection of hyaluronic acid as an adjunct treatment in the flexor tendon repair surgeries was indeed successful in reducing the post-operative adhesions, improving tendon gliding and tendon healing which is based on properties of HA as its anti-inflammatory action, cell proliferation enhancement, and increase collagen deposition, besides the lubricating action on the sliding surface of the tendon.

\section{REFERENCES}

1- Langley C. and HOBBY J.; Focus on tendon repair. The Journal of Bone and Joint Surgery, 1 (1): 1-3, 2009.

2- Kulick M., Smith S. and Hadler K.: Oral ibuprofen: Evaluation of its effect on peritendinous adhesions and the breaking strength of a tenorrhaphy. The Journal of Hand Surgery, 11 (1): pp. 110-20, 1986.

3- Moran S., Ryan C., Orlando G., Pratt C. and Michalko K.: Effects of 5-fluorouracil on flexor tendon repair. The Journal of Hand Surgery, 25 (2): pp. 242-51, 2000.

4- Nishimura K., Nakamura R. and DiZerega G.: Ibuprofen inhibition of postsurgical adhesion formation: A time and dose response biochemical evaluation in rabbits. Journal of Surgical Research, 36 (2): pp. 115-24, 1984.

5- Ozgenel G.Y. and Etöz A.: Effects of repetitive injections of hyaluronic acid on peritendinous adhesions after flexor tendon repair: A preliminary randomized, placebocontrolled clinical trial. Turkish Journal of Trauma and Emergency Surgery, 18 (1): 11-7, 2012.

6- Abate M., Pulcini D., Iorio A. and Schiavone C.: Viscosupplementation with Intra-Articular Hyaluronic Acid for Treatment of Osteoarthritis in the Elderly. Current Pharmaceutical Design, 16 (6): 631-40, 2010.

7- Hagberg L., Heinegård D. and Ohlsson K.: The Contents of Macromolecule Solutes in Flexor Tendon Sheath Fluid and Their Relation to Synovial Fluid. Journal of Hand Surgery, 17 (2): 167-71, 1992.

8- Moriya T., Zhao C., Yamashita T., An K. and Amadio P.: Effect of core suture technique and type on the gliding resistance during cyclic motion following flexor tendon repair: A cadaveric study. Journal of Orthopaedic Research, 28 (11): 1475-81, 2010.

9- Dala-Ali B., Nakhdjevani A., Lloyd M. and Schreuder F.: The Efficacy of Steroid Injection in the Treatment of Trigger Finger. Clinics in Orthopedic Surgery, 4 (4): p. $263,2012$.

10- Gallagher K.: Flexor tendon repairs. In: Cioppa-mosca J, Cahill JB, Tucker CY (eds.) Handbook of postsurgical rehabilitation guidelines of the orthopedic clinician. St Louis, Missouri: Mosby Elsevier; p. 93-110, 2008.

11- El Mikkawy Dalia M.E., Amr A.H., Gad Ahmed, Lasheen Reham and Fawaz Sheren: Comparison between early active and passive mobilization programs after hand flexor tendon repair in zone II. Egyptian Society for Rheumatology \& Rehabilitation, 40 (3): 134-40, 2013.

12- Hagberg L. and Gerdin B.: Sodium hyaluronate as an adjunct in adhesion prevention after flexor tendon surgery in rabbits. The Journal of Hand Surgery, 17 (5): pp. 93541, 1992. 